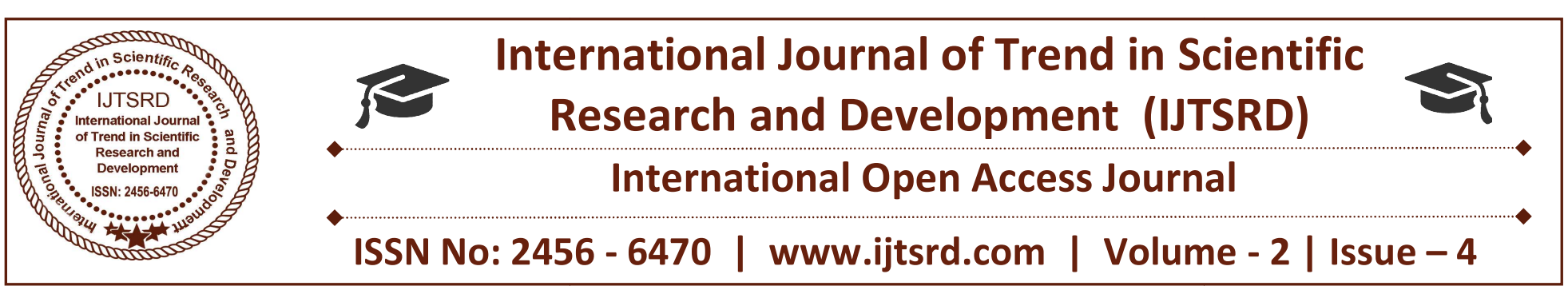

\title{
Impact of Globalization on Retail Banking Services
}

\author{
Ms. Gagan Deep Chadha ${ }^{1}$, Dr. Ritika Moolchandani ${ }^{2}$, Dr. Bimal Jaiswal ${ }^{3}$ \\ ${ }^{1}$ Research Scholar, ${ }^{2}$ Head of Department, ${ }^{3}$ Professor \\ ${ }^{1,2}$ Department of Management, Bhagwant University, Ajmer, Rajasthan, India \\ ${ }^{3}$ University of Lucknow, Uttar Pradesh, India
}

\begin{abstract}
The banking system is central to India's economy. Banks are contributing significantly in the growth and development of economy. However, banking sector in India is currently passing through an exciting and challenging phase. Though, India Banking System registered tremendous growth and reforms were introduced to improve the performance and efficiency in banking system. The reform measures have brought about sweeping changes in banking sector. The economic reforms have also generated new and powerful customers and new mix up players - public, private and foreign banks. The expectations of consumers are also growing in the competitive and changing business environment. The changing business environment has created big opportunity for Indian Banking System as demographic shifts in terms of income levels and cultural shifts in terms of life style aspirations are changing the profile of the Indian consumers. The retail banking has emerged in a big way and thus, the scope of electronic banking services has widened. Against this back drop, present paper aims to examine the impact of globalization on retail banking services in India.
\end{abstract}

Keywords : globalization, retail banking, banking reforms

\section{INTRODUCTION}

The past two decades have experienced a resurgence of international banking. The shares in country banking systems of banks with sizable foreign positions have grown tremendously. Moreover, the form of banking globalization is evolving, moving away from a system with primarily cross-border flows to a system with both cross-border transactions and more internationally diversified ownership of banks.

Other types of international transactions also have been growing, including the transactions extended by the branches and subsidiaries of parent banks that are located in host country markets, derivative use and other forms of international investments made by banks. All of these developments could have profound implications for the host countries receiving the services of globally-oriented banks, and for the parent countries of these same banks. Some implications are the immediately evident. Other implications are longer term and more structural by nature. The impetus for the globalization of banking varies by player, time, and country. Foreign bank entry into previously restricted markets have occurred in the aftermath of crises, or as a result of agreements made in conjunction with negotiations over international trade and specific forms of market access.

In view of the changing business scenario at the global level and revamping the Indian economy, Government of India introduced New Economic Policy followed by structural adjustment programme in 1991. The economic liberalization, policies adopted by India in the context of globalization followed by structural adjustment programme has widely affected the all sectors of economy. The liberalization of trade policies allowed the banks to cross their national arena and inter into a sphere of whole world. Information technology and electronic funds transfer have been the pillars of modern banking technology. The policies of globalization and economic liberalization also encouraged entry of foreign banks in India for their business operation while the trade liberalization facilitated easy flow of funds and foreign investment in banking services which also resulted drastic changes in the system of banking in 
India. Indian banking system is still pre-dominated by public sector banks while State Bank of India and its associates hold a significant share in banking business in India. In view of the global business changes, State Bank of India has also introduced revolutionary financial and credit instruments in the context of globalization and economic liberalization. The drastic improvement in technology in delivery of services such as wider use of credit-cum-debit card, credit card, smart card, virtual banking, e-banking, ATM, electronic payment system, etc. were introduced by SBI to face the competition in banking sector in India. The globalization and particularly entry of private and foreign banks has drastically improved the outreach, accessibility and quality of banking services in India. SBI and its associates are no longer far behind as compared to the private and foreign banks as far as delivery of banking services is concerned.

\section{Review of Literature:}

The explosion of Internet usage and the huge funding initiatives in electronic banking have drawn the attention of researchers towards Internet banking. Although hundreds of crores have been spent on building Internet banking systems, reports have shown that potential users may not use the systems in spite of their availability. There is need for research to identify the factors that determine acceptance of Internet banking by the users (Luarn and Lin, 2005). In their study, Luarn and Lin extended the technology acceptance model (TAM), which includes perceived ease of use and perceived usefulness, by adding 'perceived credibility', 'perceived self- efficacy' and 'perceived financial cost' to the theoretical framework. The results strongly support the extended TAM in predicting users' intentions to adopt mobile banking. Bomil and Ingoo (2002) confirmed in their study that two beliefs, ease of use and usefulness, partially explain the user's behavior in the emerging environment such as Internet banking. They introduced trust as another belief in TAM that has an impact on the acceptance of Internet banking. According to the results of their statistical analysis, trust is one of the most significant beliefs in explaining a customer's attitude towards using Internet banking. Trust has a more direct effect on an individual's behavior than perceived ease of use in the online banking context, while perceived ease of use has a greater total effect on a customer's actual use. Wang et al. (2003) also used the TAM, and they introduced 'perceived credibility' as a new factor that reflects the user's security and privacy concerns in the acceptance of Internet banking. The study also examined the effect of computer self-efficacy on the intention to use Internet banking. Based on a sample of 123 users from telephonic interview, the results strongly support the extended TAM in predicting the intention of users to adopt Internet banking. It also demonstrates the significant effect of computer selfefficacy on behavioral intention through perceived ease of use, perceived usefulness and perceived credibility. Koufaris et al. (2002) examined the impact of consumer experience and attitudes on intention to return and unplanned purchases online. The study found that perceived control and shopping enjoyment can increase the intention of new web customers to return, but seemingly do not influences repeat customers to return. Furthermore, the more often customers return to web store, the more their shopping enjoyment is determined by their product involvement. Another study, by Kambil et al. (2000), shows that senior management's support and technical issues such as information security have most significant impacts on firms that take their business online. Mols (1999) determined that bank customers are divided into an Internet banking category and a branch banking category. This segmentation grew with the increased use of the Internet. The Internet influences the future distribution channel structure in two ways: (a) it is in itself a new distribution channel for financial services; and (b) it influences consumers in a way that they invest time and resources in becoming computer literate and in familiarizing themselves with the Internet. In another of his studies, Mols (1998) compared the behavior of users of computer-based home banking systems with nonusers. The results of the Pearson's and Spearman's correlation analyses show that users of net banking are more satisfied, are less price-sensitive, have higher intentions to repurchase and provide more positive word-of-mouth than non-users. For the banks, these results indicate that in the future PC banking systems will become a stable source of revenue from a mass of loyal customers. Hitt and Frei (2002), examined whether and how characteristics or behaviors might differ between customers who use electronic delivery systems and those who use traditional channels. By using logistic regression, they concluded that demographic characteristics and changes in customer behavior following adoption of net banking account for only a small fraction of the overall differences. They also found evidence that customers who adopt online banking have greater propensity than traditional customers to adopt future 
bank products and services over a time period. Karjaluoto et al. (2002) explored the effect of different factors leading to attitude formation towards Internet banking in Finland. By using factor analysis, they determined the factors that influence the formation of attitude towards online banking and their relation to the use of online services. The study showed that prior experience of computers and technology as well as demographic factors impact heavily on consumers' online behavior. A typical online banking user is relatively young, well educated and with high level of income. Jun and Cai (2001) used the critical incident technique to uncover the key dimensions of Internet banking customers and to identify critical satisfying and dissatisfying factors, including customer service quality, banking service product quality and online systems quality. The most frequently mentioned factors of satisfaction or dissatisfaction were reliability, responsiveness, access and accuracy.

\section{Research Methodology:}

Present paper is based on secondary data collected from the publications of R B I, Government of India. Research design is empirical in nature. The data collected for the the paper has been analyzed logically and meaningfully to arrive at meaningful conclusion. The data is analyzed by calculating simple averages and percentages.

\section{Research Findings:}

An automated teller machine is a computerized telecommunications device that provides banking services anytime and anywhere, any bank to the customer. The customer is saved the risk or bother of carrying hard cash or travelers' cheque while travelling. It has also given cost savings to banks. Entry of ATMs has changed the profile of front offices in bank branches. Customers no longer need to visit branches and other places for their day to day banking transactions like cash deposits, withdrawals, cheque collection, balance enquiry, train tickets reservations, products from shopping mall, donations and charities, adding pre/paid mobile phone transactions, purchasing online products, paying bills, fees and taxes, pos etc. The penetration of ATMs across the country has increased significantly. In 2015-16 the number of ATMs witnessed a growth of approximately 20 percent to the previous year. It is not an exaggeration to said that across the country, the growth will cross the level of 2, 00,000 ATMs in next year. Also Over the years, the relative growth in on- site ATMs has been much more than of off-site ATMs. Approximately 70 percent nt of the total ATMs belonged to the public sector banks as at end March 2016 (Table 1).

\section{Table 1}

\section{ATMs of Scheduled Commercial Banks}

\begin{tabular}{|l|l|l|l|l|l|}
\hline $\begin{array}{l}\text { Sr. } \\
\text { No. }\end{array}$ & $\begin{array}{l}\text { Bank } \\
\text { group }\end{array}$ & $\begin{array}{l}\text { On } \\
\text { site } \\
\text { ATMs }\end{array}$ & $\begin{array}{l}\text { Off } \\
\text { site } \\
\text { ATMs }\end{array}$ & $\begin{array}{l}\text { Total } \\
\text { Number } \\
\text { of } \\
\text { ATMs }\end{array}$ & $\begin{array}{l}\text { Off site } \\
\text { ATMs } \\
\text { as \% of } \\
\text { total } \\
\text { ATMs }\end{array}$ \\
\hline I & $\begin{array}{l}\text { Public } \\
\text { sector } \\
\text { banks }\end{array}$ & 80399 & 62060 & 142459 & 43.56 \\
\hline II & $\begin{array}{l}\text { Private } \\
\text { sector } \\
\text { banks }\end{array}$ & 20724 & 33708 & 54432 & 61.93 \\
\hline III & $\begin{array}{l}\text { Foreign } \\
\text { banks }\end{array}$ & 261 & 799 & 1060 & 75.38 \\
\hline IV & $\begin{array}{l}\text { All SCBs } \\
\text { (I+II+III) }\end{array}$ & 101384 & 96567 & 197951 & 48.28 \\
\hline
\end{tabular}

Source: www.rbi.com-RBI Statistical Report, 2016

Plastic money is the alternative to the cash or standard money. These cards are electronic card issued by a bank which allows bank clients access to their account to withdraw cash or pay for goods and services. It is convenient to carry. The various Plastic money/cards include ATM cards, Debit Card, ATM cum Debit Card, Credit Card. Plastic money was a delicious gift to Indian market. Now several new features added to plastic money to make it more attractive. Credit card is a financial instrument, which can be used more than once to borrow money or buy products and services on credit. Banks, retail stores and other businesses generally issue these. On the basis of their credit limit, they are of different kinds like classic, gold or silver.There has been growth in issuance of debit and credit cards by public and private sector banks. However a Debit card is much higher as compared to credit cards and they remain a preferred mode of transactions in India. While public sector banks have been frontrunners in issuing debit cards, new private sector banks continue to lead in the number of credit cards issued (Table 2). 
International Journal of Trend in Scientific Research and Development (IJTSRD) ISSN: 2456-6470

Table 2

Credit and Debit Cards Issued by Banks

(In Millions)

\begin{tabular}{|l|l|l|l|l|l|}
\hline $\begin{array}{l}\text { Sr. } \\
\text { No. }\end{array}$ & Bank group & $\begin{array}{l}\text { Outstanding Number of } \\
\text { Credit Cards }\end{array}$ & $\begin{array}{l}\text { Outstanding Number of } \\
\text { Debit Cards }\end{array}$ \\
\hline & & 2015 & 2016 & 2015 & 2016 \\
\hline I & Public sector banks & 4308449 & 5048354 & 459626728 & 548501376 \\
\hline II & Private sector banks & 12075440 & 14731014 & 90787177 & 102569319 \\
\hline III & Foreign banks & 4726764 & 4725851 & 3037648 & 3043526 \\
\hline IV & All SCBs (I+II+III) & 21110653 & 24505219 & 553451553 & 654114221 \\
\hline
\end{tabular}

Source:www.rbi.com-RBI Statistical Report,2016

Gone are those days when depositing amount in a friend, relatives or others account would take a few business days. World is moving faster and now there are various methods for fund transfer to another account within nix time. According to Reserve Bank of India, NEFT is a nation-wide payment system to facilitate one-to-one funds transfer. Under NEFT, individuals, firms and corporate can electronically transfer funds from any bank branch to any individual, firm or corporate having an account with any other bank branch in the country participating in the Scheme. The funds under NEFT can be transferred by individuals, firms or corporate maintaining accounts with a bank branch. Even individuals not having a bank account can deposit cash at the NEFT-enabled branches with instructions to transfer funds using NEFT. However, such cash remittances will be restricted to a maximum of Rs.50,000/- per transaction. Such walk-in-customers have to furnish full details including complete address, telephone number, etc. NEFT, thus, also help in transfer of funds even without having a bank account. This is a simple, secure, safe, fastest and cost effective way to transfer funds especially for Retail remittances (Table 3 )

Table 3

National Electronic Funds Transfer by Banks

(Amount in Rs. Millions)

\begin{tabular}{|c|c|c|c|c|c|}
\hline \multirow{3}{*}{$\begin{array}{l}\text { Sr. } \\
\text { No. }\end{array}$} & \multirow{3}{*}{ Bank group } & \multicolumn{4}{|c|}{ Total Outwards Debits } \\
\hline & & \multicolumn{2}{|c|}{$20150 / N: 2450=04 / 0$} & \multicolumn{2}{|l|}{2016} \\
\hline & & $\begin{array}{l}\text { No. of } \\
\text { Transactions }\end{array}$ & Amount & $\begin{array}{l}\text { No. of } \\
\text { Transactions }\end{array}$ & Amount \\
\hline I & Public sector banks & 57362752 & 2969292.87 & 59866187 & 4105223.86 \\
\hline II & Private sector banks & 36141523 & 2437423.71 & 50192033 & 3594872.95 \\
\hline III & Foreign banks & 11605703 & 1404018.01 & 14357901 & 1833517.34 \\
\hline IV & All SCBs (I+II+III) & 105109978 & 6810734.59 & 124416121 & 9533614.15 \\
\hline
\end{tabular}

Source:www.rbi.com-RBI Statistical Report ,2016

It can be see that the penetration of NEFT is increasing day by day across the country. The customers of bank are enjoying this simple, secure, safe, fastest and cost effective fund transfers. As compare to year 2015, number of inward and outward transactions has increased in 2016. As the same comparison from 2015, the number of transactions of outward and inward witnessed a growth of 18 and 21 percent approximately. In all SCBs the percentage of public sector banks are performing much better than to other banks. With the oldest and wide networking

of public sector banks, customers are showing more trust on it and take interest for using their fund transfer system as compare to private sector banks and foreign banks (Table 4). 
Table 4

NEFT -National Electronic Funds Transfer by Banks

(Amount in Rs. Millions)

\begin{tabular}{|l|l|l|l|l|l|}
\hline \multirow{2}{*}{$\begin{array}{l}\text { Sr. } \\
\text { No. }\end{array}$} & Bank group & \multicolumn{4}{|l|}{ Received Inward Credits } \\
\cline { 3 - 6 } & & $\mathbf{2 0 1 5}$ & $\mathbf{2 0 1 6}$ \\
\hline & & $\begin{array}{l}\text { No. of } \\
\text { Transactions }\end{array}$ & Amount & $\begin{array}{l}\text { No. } \\
\text { Transactions }\end{array}$ & Amount \\
\hline I & Public sector banks & 74835617 & 3538131.40 & 89990261 & 5155302.74 \\
\hline II & Private sector banks & 25179809 & 2497392.84 & 31668368 & 3554414.44 \\
\hline III & Foreign banks & 3316065 & 974100.34 & 4127832 & 1278438.34 \\
\hline IV & All SCBs (I+II+III) & 103331491 & 7009624.58 & 125786461 & 9988155.52 \\
\hline
\end{tabular}

Source-www.rbi.com-RBI Statistical Report, 2016

There has been a sustained growth of RTGS in 2016. In terms of both volume and value of all types of electronic transactions of scheduled commercial banks has increasing gradually. The transactions which are more than 2,00,000 lakh rupees people are using this safe, secure and fastest system. On the basis of table 5 and Table 6, it can be see that the volume of private sector banks and foreign banks is less than public sector banks but their value is more than public sector banks. It means, the transactions which are above two lakh people are showing more trust on these two sector banks.

\section{Table 5}

RTGS (Bank Wise RTGS Inward) By Banks

(Volume In Million, Value In Rs. Billion)

\begin{tabular}{|c|c|c|c|c|c|c|c|c|c|}
\hline \multirow{3}{*}{$\begin{array}{l}\text { Sr. } \\
\text { No. }\end{array}$} & \multirow{3}{*}{$\begin{array}{l}\text { Bank } \\
\text { group }\end{array}$} & \multicolumn{8}{|c|}{ Bank wise RTGS inward } \\
\hline & & \multicolumn{4}{|c|}{2015} & \multicolumn{4}{|l|}{2016} \\
\hline & & Volume & $\%$ & Value & $\%$ & Volume & $\%$ & Value & $\%$ \\
\hline $\mathbf{I}$ & $\begin{array}{l}\text { Public } \\
\text { Sector } \\
\text { Banks }\end{array}$ & 4910474 & 50.77 & 29325.01 & 50.77 & 4933263 & 50.01 & 31982.07 & 31.97 \\
\hline II & $\begin{array}{l}\text { Private } \\
\text { Sector } \\
\text { Banks }\end{array}$ & 3694316 & 38.19 & 32453.50 & 38.19 & 3855320 & 39.08 & 38610.49 & 38.59 \\
\hline III & $\begin{array}{l}\text { Foreign } \\
\text { Banks }\end{array}$ & 860708 & 8.90 & 18232.66 & 8.90 & 830143 & 8.42 & 19109.88 & 19.10 \\
\hline IV & $\begin{array}{l}\text { All SCBs } \\
(I+I I+I I I)\end{array}$ & 9465498 & 97.86 & 80011.16 & 97.86 & 9618726 & 97.51 & 89702.45 & 89.66 \\
\hline
\end{tabular}

Source-www.rbi.com-RBI Statistical Report, 2016 
Table 6

RTGS (Bank Wise RTGS Outward) By Banks

(Volume In Million, Value In Rs Billion)

\begin{tabular}{|c|c|c|c|c|c|c|c|c|}
\hline \multirow[t]{3}{*}{ Bank group } & \multicolumn{8}{|c|}{ Bank wise RTGS outward } \\
\hline & \multicolumn{4}{|c|}{2015} & \multicolumn{4}{|l|}{2016} \\
\hline & Volume & $\%$ & Value & $\%$ & Volume & $\%$ & Value & $\%$ \\
\hline $\begin{array}{l}\text { Public } \\
\text { Sector } \\
\text { Banks }\end{array}$ & 5294842 & 54.74 & 29652.66 & 54.74 & 5265806 & 53.38 & 33010.63 & 33.00 \\
\hline $\begin{array}{l}\text { Private } \\
\text { Sector } \\
\text { Banks } \\
\end{array}$ & 3660583 & 37.84 & 33292.35 & 37.84 & 3841837 & 38.95 & 39827.16 & 39.81 \\
\hline $\begin{array}{l}\text { Foreign } \\
\text { Banks } \\
\end{array}$ & 444862 & 4.60 & 18545.84 & 4.60 & 434754 & 4.41 & 19249.88 & 19.24 \\
\hline $\begin{array}{l}\text { All SCBs } \\
(I+I I+I I I)\end{array}$ & 9400287 & 97.18 & 81490.85 & 97.18 & 9542397 & 96.74 & 92087.67 & 92.05 \\
\hline
\end{tabular}

source-www.rbi.com-RBI Statistical Report , 2016

Mobile phones as a medium for providing banking services have been attaining increased importance. Reserve Bank brought out a set of operating guideline on mobile banking for banks in October 2008, according to which only banks which are licensed and supervised in India and have a physical presence in India are permitted to offer mobile banking after obtaining necessary permission from Reserve Bank. The guidelines focus on systems for security and inter-bank transfer arrangements through Reserve Bank's authorized systems. On the technology front the objective is to enable the development of interoperable standards so as to facilitate funds transfer from one account to any other account in the same or any other bank on a real time basis irrespective of the mobile network, a customer has subscribed to. Mobile users have found convenience in the use of mobile phone to transfer money. There is a remarkable increasing trend in this electronic payment. The value of mobile transactions jumped more than two times in just one year and the total value of money transferred through mobile phones surged to Rs 464401645 crore in 2015-16 from Rs 168901572 crore in 2014-15. In all scheduled commercial banks the percentage of private sector banks are performing much better than to other banks. They are transferring more money through mobile phones than ever before.

\section{Conclusion:}

In view of the changing business scenario at the global level and revamping the Indian economy, Government of India introduced New Economic Policy followed by structural adjustment programme in 1991. The economic liberalization, policies adopted by India in the context of globalization followed by structural adjustment programme has widely affected the all sectors of economy. The liberalization of trade policies allowed the banks to cross their national arena and inter into a sphere of whole world. Information technology and electronic funds transfer have been the pillars of modern banking technology. The policies of globalization and economic liberalization also encouraged entry of foreign banks in India for their business operation while the trade liberalization facilitated easy flow of funds and foreign investment in banking services which also resulted drastic changes in the system of banking in India. Electronic banking services, whether delivered online or through other mechanisms, have spread quickly in recent years. The threat of new entrants has led many banks to offer e-finance ranging from basic to fully integrated internet services. This trend seems to have accelerated in India as well. The recent history of financial crises in the developing countries has clearly shown the critical importance of sound regulation and supervision as a means of defending financial systems against distress and disorder. 


\section{References:}

1) Bomil, S. \& Ingoo, H. (2002) Effect of Trust On Customer Acceptance of Internet Banking. Electronic Commerce Research and Applications, $1,247-263$.

2) Hitt, L. \& Frei, F. (2002) Do Better Customers Utilize Electronic Distribution Channels? The Case of P C Banking. Management Science, 48, 732-748.

3) Jun, M. \& Cai, S. (2001) The Key Determinants of Internet Banking Service Quality: A Content Analysis. International Journal of Bank Marketing, 19, 276-291.

4) Karjaluoto, H., Mattila, M. \& Pento, T. (2002) Factors Underlying Attitude Formation Towards Online Banking In Finland, International Journal of Bank Marketing, 20, 261- 272.

5) Koufaris, M., Kambil, A. and Labarbera, A.P. (2002) Customer Behavior In Web Based Commerce: An Empirical Study. International Journal Of Electronic Commerce, 6,

6) Luarn, P. \& Lin, H. (2005) Toward An Understanding of The Behavioral Intention To Use Mobile Banking. Computers In Human Behavior, 21, 873-891.

7) Mols, N. (1998) The Behavioral Consequences of PC Banking. International Journal Of Bank Marketing, 16, 195-201.

8) Mols, N. (1999) 'The Internet and The Banks' Strategic Distribution Channel Decisions. International Journal of Bank Marketing, 17, 295300 .

9) Wang, Y.S., Wang, Y.M., Lin, H.H. \& Tang, T.I. (2003) Determinants of User Acceptance Of Internet Banking: An Empirical Study', International Journal of Service Industry Management, 14, 501-519. 